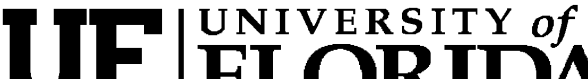 FLORIDA \\ IFAS Extension
}

\section{Pesticide Labeling: Identification Numbers ${ }^{1}$}

\author{
Frederick M. Fishel $^{2}$
}

This document describes identification numbers seen on the pesticide label. Examples of various identification numbers are provided and their meanings explained.

\section{Introduction}

The EPA registration number and the establishment number (Figure 1) are required on all pesticide products. The purpose of an identification number is to provide a unique product number for regular registrations, distributor registrations, Special Local Need registrations, and Experimental Use Permits.

\section{EPA Registration Number}

The EPA registration number indicates which company holds the registration for the pesticide product, and in which sequence the product was submitted to the EPA by the company. Before a pesticide product is registered under the Federal Insecticide, Fungicide, and Rodenticide Act (FIFRA), it is assigned an EPA file symbol which is comprised of the company number followed by a series of letters representing the potential product number. Product numbers are assigned sequentially to each company. The letters are used to indicate that the product is not registered. The letters come from the word, "REGULATION." Each letter represents a number starting with "1 (one)," and ending in "0 (zero)." Accordingly, $\mathrm{R}=1, \mathrm{E}=2, \mathrm{G}=3, \mathrm{U}=4, \mathrm{~L}=5$, $\mathrm{A}=6, \mathrm{~T}=7, \mathrm{I}=8, \mathrm{O}=9$, and $\mathrm{N}=0$. Therefore, if 6767-EGN were registered, it would become EPA Registration Number 6767-230. "6767" is the number identifying the company holding the registration and " 230 " is the number identifying that specific product. EPA has no required location for companies to place their registration number on the label, but it is usually found on the front or back panel of the product label, and near the company's name and address.

\section{Distributor Numbers}

FIFRA permits distribution or sale of a registered product under a distributors name and address. This is called "supplemental distribution." Distributor labels must be the same as that for the federally-registered product except for: product name, name and address of distributor, distributor number, establishment number, and any claims that

1. This document is PI-108, one of a series of the Pesticide Information Office, Florida Cooperative Extension Service, Institute of Food and Agricultural Sciences, University of Florida. Original publication date March 2006. Visit the EDIS Web Site at http://edis.ifas.ufl.edu.

2. Frederick M. Fishel, associate professor, Agronomy Department, and Director, Pesticide Information Office; Florida Cooperative Extension Service, Institute of Food and Agricultural Sciences, University of Florida, Gainesville, FL 32611.

The use of trade names in this publication is solely for the purpose of providing specific information. UF/IFAS does not guarantee or warranty the products named, and references to them in this publication does not signify our approval to the exclusion of other products of suitable composition. Use pesticides safely. Read and follow directions on the manufacturer's label.

The Institute of Food and Agricultural Sciences (IFAS) is an Equal Opportunity Institution authorized to provide research, educational information and other services only to individuals and institutions that function with non-discrimination with respect to race, creed, color, religion, age, disability, sex, sexual orientation, marital status, national origin, political opinions or affiliations. U.S. Department of Agriculture, Cooperative Extension Service, University of Florida, IFAS, Florida A. \& M. University Cooperative Extension Program, and Boards of County Commissioners Cooperating. Larry Arrington, Dean 


\section{Bayer CropScience}

\section{ALIETTE ${ }^{\Theta} W D G_{\text {brand Fungicide }}$}

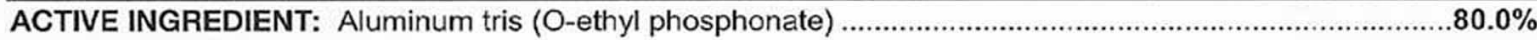

INERT INGREDIENTS:

$20.0 \%$

EPA Reg. No. 264-516

EPA Est. No. 264-MO-02

\section{KEEP OUT OF REACH OF CHILDREN CAUTION}

Figure 1. The EPA registration and establishment numbers are required on all product labels.

are deleted from the label. No new claims may be added. Distributors may not amend their product labels separately. Only the basic registrant can amend a product's registered label. Distributor products will bear the EPA registration number of the basic product, followed by a dash, and then followed by the distributor's company number. For example, Company A has a registered product, Kill It Dead Herbicide, EPA registration number 262-598. Company A enters into a supplemental distribution agreement with Company $\mathrm{B}$ as a distributor. EPA receives all of the documentation explaining the arrangements between the two companies, and then assigns to Company B the number, 10007. Company $\mathrm{B}$ then markets the herbicide with the name, "Make It Brown Herbicide." Company B's registration number for that product will then have three sets of numbers partitioned by dashes that readily identify the product as a distributor product. In this case, the registration number would be 262-598-10007. If there were to be any amendments to the label, they would have to be done by Company A.

\section{EPA Establishment Number}

The establishment number indicates the final establishment at which the product was produced. A facility that produces pesticides must have a company number before an EPA establishment number is assigned. This number is often grouped together with the EPA registration number, but that is not a requirement. State abbreviations, such as FL, MS, or $\mathrm{NC}$, will appear after the company number. The example shown in Figure 1 contains "MO," indicating that the product was manufactured in Missouri.

\section{Special Local Need (SLN) Registration Number}

The SLN registration number is also known as a FIFRA Section 24(c) registration number (see EDIS Document PI-95, Special local need pesticide registrations--24(c) http://edis.ifas.ufl.edu/PI132). The number is written as "EPA SLN No." followed by the two letter state designation, then the last two digits of the year of issuance, and finally a four digit number which is the consecutive number of registrations that the registering state has issued in that particular year. For example, if the company $\mathrm{ABC}$ applied for a section 24(c) registration in Florida and it was the $34^{\text {th }}$ SLN registration accepted by Florida in the year 1995, then the 24(c) registration number would by EPA SLN No. FL950034.

\section{Experimental-use permit number}

An experimental use-permit allows a company to develop data on either a new product or a new use site for a future full product registration (see EDIS Document PI-56, Experimental-use permits http://edis.ifas.ufl.edu/PI093). For example, the company $\mathrm{ABC}$ has a company number of 98979 and applies for an experimental-use permit to collect data on the crop lettuce and no tolerance is yet established for lettuce. The experimental-use permit number that EPA assigns to the product would be 
98979-EUP-152, indicating this is the $152^{\text {nd }}$ permit

for which this company has applied.

\section{Additional information}

Fishel, F.M. 2005. Experimental-use permits. UF/IFAS EDIS Extension Document PI-56. http://edis.ifas.ufl.edu/PI093.

Fishel, F.M. 2005. Interpreting pesticide label wording. UF/IFAS EDIS Extension Document PI-34. http://edis.ifas.ufl.edu/PI071

Fishel, F.M. 2005. Special local need pesticide registrations--24(c). UF/IFAS EDIS Extension Document PI-95. http://edis.ifas.ufl.edu/PI132 